\title{
Current smoking behaviour among rural South African children: Ellisras Longitudinal Study
}

\author{
Ramaijane J Mashita ${ }^{1 \dagger}$, Mahlapahlapana J Themane ${ }^{1 \dagger}$, Kotsedi D Monyeki ${ }^{{ }^{*}+}$ and Han CG Kemper ${ }^{3 \dagger}$
}

\begin{abstract}
Background: The use of tobacco products is the major cause of chronic diseases morbidity and mortality. Most smokers start the smoking habits from childhood and adolescent stages.

Method: This was a cross-sectional study. A total of 1654 subjects (854 boys and 800 girls), aged 11 to 18 years, who were part of the Ellisras Longitudinal Study completed the questionnaire. Association between tobacco products use and habits, attitudes and beliefs were explored in this study. Logistic regression was used to estimate the association.

Results: The prevalence of tobacco product use increases with increasing (4.9 to 17.1\%) age among boys whereas girls do not smoke cigarette but only considerable number (1.0 to 4.1\%) use home made tobacco products (pipe and snuff) among the Ellisras rural children. Parents and grand parents play a significant (about 50\%) role in influencing smoking behaviour among the Ellisras rural children. Seeing actors smoking on TV shows was positively associated $(p<0.05)$ with smoking $(O R=2.395 \% \mathrm{Cl}(1.3-4.1$ and $\mathrm{OR}=2.395 \% \mathrm{Cl} 1.3-4.1$ after adjusting for age and gender). However, women who smoke cigarette were significantly $(p<0.001)$ associated with success and success and wealth $(\mathrm{OR}=2.8,95 \% \mathrm{Cl}$ 1.5-5.2) even after adjusting for age and gender ( $\mathrm{OR}=2.995 \% \mathrm{Cl}$ 1.5-5.4).
\end{abstract}

Conclusion: The usage of tobacco products was high among older boys. Girls did not smoke cigarette. This tobacco use behaviour mirrors the cultural norms and adult behaviour. The association of this tobacco used products with biological parameters will shed more light on the health of these children over time.

\section{Background}

Tobacco use is a major public health concern, not only because of its indisputable impact on the health of both smokers and non-smokers, but because it is one of the preventable causes of morbidity and mortality. Smoking is a lifestyle factor that is strongly associated with certain forms of cancer [1-4] and cardiovascular diseases [2,5,6]. Internationally, public awareness and beliefs about the health risks of smoking have increased considerably, especially among adolescents and this was reflected in declining smoking rates in numerous developed countries [7]. However, in developing countries cigarette smoking is likely to increase tremendously in the next two decades as the tobacco industry concentrates its marketing on youth [8]. Indigenous knowledge, practice

\footnotetext{
* Correspondence: dmonyeki@yahoo.com

† Contributed equally

${ }^{2}$ Chronic Disease of lifestyle unit, Medical Research Council, Tygerberg, 7505, South Africa

Full list of author information is available at the end of the article
}

and traditional beliefs are sometimes also blamed for this escalating behaviour in the developing countries [9].

There is an increasing public awareness of health risks of tobacco products usage which is reflected in the declining rate of cigarette smoking in the developed countries, while in developing countries the rate is increasing [10-12]. For example, tobacco consumption, amongst adolescents in South Africa, that began in the 1960s, has peaked up in the last decade of the twentieth century [13]. In 1992, Martin et al. [7] reported that 31.5\% of South Africans, 18 years and older smoked. This figure increased to $34 \%$ in 1995 which includes younger children who start smoking earlier [14]. Subsequently, Reddy et al. [15] reported that about one in five learners (21.1\%) of Grades 8 to 11 in public schools were classified as current smokers nationally while the South African Demographic Health Survey [16] reported 3.3 to $7.0 \%$ for females. About 1.0 to $23.7 \%$ male adolescents aged 15 to 19 years old were reported to have ever use tobacco product daily.

\section{() Biomed Central}


This trend is indeed worrying especially with an increase of incidents of smokers among younger children of which little is known about their behaviour, beliefs and practices of tobacco products given the fact that these communities are traditionally known to be conservative. This study therefore, was intended to investigate the current smoking behaviour among rural South African children aged 11 to 18 years who are part of the ongoing Ellisras Longitudinal Study cross-sectionally.

\section{Methods}

\section{Geographical area}

Ellisras is a deep rural area situated within the northwestern area of the Limpopo Province, South Africa. The population is about 50, 000 residing in 42 settlements [17]. These villages are approximately $70 \mathrm{~km}$ from the Ellisras town $\left(23^{\circ} 40 \mathrm{~S} 27^{\circ} 44 \mathrm{~W}\right)$, now known as Lephalale, adjacent to Botswana border. The Iscor coal mine, Matimba and Medupi electricity power stations are the major sources of employment for many of the Ellisras residents, whereas the remaining workforce is involved in subsistence farming and cattle rearing, while the minority is in education and civil services. Unemployment, poverty and low-life expectancy seem to play a significant role in the rural South African population of which Ellisras rural area people are not an exception $[18,19]$. Schools in these villages are characterized by poor infra-structure, lack of teaching and learning resources (like laboratories and libraries) and lack of recreational and health facilities [20]. These schools are under-performing in terms of literacy and mathematics [21-23].

\section{Research design and sampling}

The Ellisras Longitudinal Growth and Health Study (ELS) initially followed a cluster sampling method $[24,25]$. In brief, the study was undertaken at 22 schools (10 pre-schools and 12 primary schools). The selection was done randomly from 68 schools within the Ellisras area. Birth records were obtained from the principals of each school. Only those records that were verified against health clinic records were used to determine the age of each potential participant. Each of the 22 selected schools was assigned a grade with the expectation that most of the children in a particular age category (i.e. 3, $4, \ldots 9,10)$ would be found in that grade.

A total of 1654 children ( 854 boys and 800 girls) aged between 11 to 18 years who are part of the ELS participated in the study during the period 1 March to 3 May 2005 from the 1771 (923 boys and 848 girls) who participated in the anthropometric measurements of November 2003. The Ethics Committee of the South African Medical Research Council granted ethical approval prior to the survey and the parents or guardians provided informed consent. The children signed the assent form after receiving verbal assent from the project principal investigator.

\section{Data collection}

The questionnaire that covers important concepts relating to tobacco products from Birth to Ten Study [26], the Amsterdam Growth and Health Longitudinal Study [27] and the first South African National Youth Risk Behaviour Survey [15] were studied. In these previous studies perceptions regarding teachers and other role models, who use tobacco products, attitudes based on exposure to the media and experimentation with tobacco products were thoroughly investigated. Lastly, the focus was directed at the South African Tobacco Control Legislation. Based on the definition of tobacco products, a list of concepts was developed. Questions addressing relevant concepts (knowledge, practice, attitudes, beliefs and advertisement) of the present study were extracted from the previously validated questionnaire. An expert panel was then convened to recommend which questions should be included in the knowledge, practices, attitudes and beliefs concepts. The principal investigator with the help of the Ellisras local teachers translated the questionnaire from English to the two local spoken languages (Northern Sotho and Setswana) and then translated back to English. The translation back to English showed no disparity with the Northern Sotho and Tswana languages (Ellisras rural area local language).

\section{Definition of concepts}

A current smoker was defined as anyone who smoked at least one cigarette or any other type of tobacco product like pipe, snuff, home-made tobacco or indigenous tobacco per day at the time of survey. Those who never smoked a tobacco product at the time of the survey were considered non smokers. The attitude of the children's relatives and acquaintances towards cigarette smoking were measured indirectly by asking the children if their relatives and acquaintances allow people to smoke freely in their presence. In the interview, considerable participants were asked how strongly they believed in certain statements regarding smoking habits, attitudes and their beliefs on tobacco products. i) A packet contains ten cigarettes, ii) Box of BB or boxer weighs $12.5 \mathrm{~g}$ and iii) Snuff or powder-like tobacco product, Thekgwane or container carries $15 \mathrm{~g}$ of snuff.

\section{Quality control}

All selected field workers underwent intensive training for one week prior to the survey. The inter tester (between fieldworkers) and intra tester (principal investigator and field workers) technical error of measurements ranged from 97 to $100 \%$ in agreement with the coding of the 
beliefs and attitude responses of the smoking questionnaire, whereas questionnaires relating to the knowledge of tobacco ranges from 95 to $98 \%$ agreement.

\section{Data analysis}

All analyses were performed using the SPSS Version 14.0 (SPSS Inc., Chicago, IL, USA). This was a cross-sectional study. Analyses were run for descriptive statistics by gender and age. Chi-squared tests were used to compare sets of nominal data that had larger frequency counts, whereas the Fisher's exact test was used when frequency cells were small (less than five or ten) between genders. Logistic Regression analysis was applied to determine the association between tobacco products use as well as their beliefs and attitudes. The statistical significance was set at $\mathrm{P}<0.05$.

\section{Results}

Table 1 presents prevalence of tobacco usage by age group and gender. The prevalence of cigarette smoking increased with increasing age (ranged from 4.9 to $17.1 \%$ ) and was high among boys aged 11 to 18 years as compared to the usage of pipe (ranged from 1.4 to 3.9\%) and snuff (1.0 to $3.9 \%$ ) (Table 1). No Ellisras rural girls aged 11 to 18 years smoked cigarette. The prevalence of snuff usage ranged between 0.7 to $4.1 \%$ for girls aged 11 to 18 years. There was no significant difference between the prevalence of pipe and snuff usage between boys and girls through out the age range (Table 1 ).

Table 2 presents frequency and percentage frequency for positive responses on beliefs, habits and knowledge of home made usage of tobacco products for Ellisras rural children aged 11 to 18 years. The use of tobacco product among the Ellisras rural children family circle as reported by boys ranged from $5.7 \%$ to $24.9 \%$ and girls 0 to $27.8 \%$. A considerable number of children $(52 \%$ boys and $46 \%$ girls) were sent by somebody to buy smoking products in the local shop. Nine percent $(9.0 \%)$ of boys and $5.8 \%$ girls believed they would use the tobacco product when they were adults.

There were relationships of various indicators of attitudes towards smoking with experimentation. For both boys and girls there was an effect on the perception of smoking when observing TV stars, men and women smoking. For example, almost similar number of boys and girls (20\%) in Ellisras rural area admired TV stars and men who smoke cigarettes while women who used the tobacco products were less admired by many children (Table 3 ). Fifty point eight percent $(50.8 \%)$ of boys and $50.9 \%$ of Ellisras rural girls watch Television actors in the movies using tobacco products (Table 2). There was no significant difference in the proportion of boys and girls who regarded men $(19.7 \%$ vs $18.8 \%$ for cigarette, $15.2 \%$ vs $15.1 \%$ for snuff) and women $(11.6 \%$ vs $13.4 \%$ for cigarette, 14.2 vs $15.6 \%$ for snuff) using tobacco products a symbols of being cool, rich and successful (Table 3).

Table 4 presents odd ratio, 95\% confidence interval for the association of tobacco product usage and habits and attitudes towards the tobacco product among the Ellisras rural children. There was a significant $(\mathrm{p}<0.001$ to 0.05 ) association between the tobacco products use and the success of TV stars (OR $2.395 \%$ CI 1.3; 3.4) and smoking women (OR $=2.895 \%$ CI 1.5; 5.2; OR $2.995 \%$ CI $1.5 ; 5.4$ ) even after adjusting for age and gender. The use of tobacco products and the rights of using tobacco products were significantly associated (OR 2.32 95\% CI 1.4 ; 3.8 and OR $2.3195 \%$ CI $1.4 ; 3.9$ ) even after adjusting for age and gender (Table 4).

Figure 1 shows the estimated period during which rural boys first started to use tobacco products by age group. The majority of children started smoking around the age of seven years. Figure 2 presents the amount of tobacco products used by Ellisras rural boys aged 11 to 18 years. The majority of participants (cigarette $=34.6 \%$; pipe $=16.2 \%$; snuff $=16.9 \%$ ) did not know the amount of tobacco they used per week as they relied on others or use home made tobacco product while few children $(10 \%)$ reported to use less than seven packets of cigarettes or seven grams of BB or boxer a week. Figure 3 presents the influential people in the use of tobacco product among the Ellisras rural children by age group. The majority (almost 50\%) of younger children (11-14 years) were influenced by their parents and grand parents

Table 1 Prevalence of smoking by age group and gender for Ellisras rural children aged 11 to 18 years

\begin{tabular}{|c|c|c|c|c|c|c|c|c|c|c|}
\hline \multirow[t]{3}{*}{ Age range (years) } & \multicolumn{5}{|c|}{$\begin{array}{l}\text { Boys } \\
\text { (total } \mathrm{N}=854 \text { ) }\end{array}$} & \multicolumn{5}{|c|}{$\begin{array}{l}\text { Girls } \\
\text { (total } N=800 \text { ) }\end{array}$} \\
\hline & $\mathrm{N}$ & Cigarette & Pipe & Snuff & Total & $\mathrm{N}$ & Cigarette & Pipe & $\begin{array}{l}\text { Snuff/ } \\
\text { chew }\end{array}$ & Total \\
\hline & & (n) $\%$ & (n) $\%$ & (n) $\%$ & (n) $\%$ & & (n) $\%$ & (n) \% & (n) $\%$ & (n) $\%$ \\
\hline $11-12$ & 142 & (7) 4.9 & (2) 1.4 & (2) 1.4 & $(11) 7.8$ & 134 & $0(0)$ & (1)0.7 & (3) 2.2 & (4)3.0 \\
\hline $13-14$ & 205 & (19)9.3 & (6) 2.9 & (8)3.9 & (33) 16.1 & 196 & $0(0)$ & (2) 1.0 & (8)4.1 & (10)5.1 \\
\hline $15-16$ & 308 & (32) 10.4 & $(12) 3.9$ & (6) 1.9 & (50) 16.2 & 294 & $0(0)$ & (4) 1.4 & (2)0.7 & (6)2.0 \\
\hline $17-18$ & 199 & (34) 17.1 & (7) 3.5 & (2)1.0 & (43)21.6 & 176 & $0(0)$ & (4) 2.3 & (4) 1.7 & (8) 4.5 \\
\hline
\end{tabular}


Table 2 Frequencies and percentage frequencies for positive responds on believes, advertisement, habitual and knowledge of homemade use of tobacco product $s$ for Ellisras rural children (boys = 854; girls $=800$ )

\begin{tabular}{|c|c|c|c|c|}
\hline & & \multicolumn{2}{|l|}{$\begin{array}{l}\text { Boys } \\
\text { (n) \% }\end{array}$} & $\begin{array}{l}\text { Girls } \\
\text { (n) } \%\end{array}$ \\
\hline \multicolumn{5}{|c|}{ Habits of Ellisras children of tobacco product } \\
\hline \multicolumn{5}{|c|}{ 1. During the past seven days how many people use tobacco product at your home? } \\
\hline & less than ten & more than ten & less than ten & More than ten \\
\hline Smoked cigarette & $(268) 31.4$ & (5)0.6 & $(225) 28.1$ & (4) 0.5 \\
\hline Smoked tobacco & (256)30.0 & (2) 0.2 & $(216) 27.0$ & (3) 0.4 \\
\hline Use snuff & (193)22.6 & (8) 0.9 & $(179) 22.4$ & (7) 0.9 \\
\hline Chew tobacco & $(5) 0.6$ & $0(0)$ & (2) 0.3 & $0(0)$ \\
\hline \multicolumn{5}{|c|}{ 2. Does anyone send you to the shop to buy the following tobacco product for their own use } \\
\hline Cigarette & & & $(444) 52.0$ & $(368) 46.0$ \\
\hline Pipe tobacco & & & $(223) 26.1$ & $(202) 25.3$ \\
\hline Snuff & & & $(248) 29.0$ & (238)29.8 \\
\hline Chew tobacco & & & $(1) 0.1$ & $(4) 0.5$ \\
\hline \multicolumn{5}{|c|}{ 3. Do the following people smoke cigarette or pipe? Your: } \\
\hline Mother or Father & & & $(213) 24.9$ & $(222) 27.8$ \\
\hline Grand parents & & & $(189) 22.1$ & $(193) 24.1$ \\
\hline Brothers or sisters & & & $(171) 20.0$ & $(157) 19.6$ \\
\hline Uncle or Aunts & & & $(153) 17.9$ & (144) 18.0 \\
\hline Friends & & & $(115) 13.5$ & (98) 12.3 \\
\hline \multicolumn{5}{|c|}{ Believes of Ellisras children of tobacco product } \\
\hline \multicolumn{5}{|c|}{ Do you think it is acceptable } \\
\hline 1. For people to sm & & & $(140) 16.4$ & (118) 14.8 \\
\hline 2. For people to ch & olic places. & & $(178) 20.8$ & $(174) 21.8$ \\
\hline \multicolumn{5}{|c|}{ Do you believe that people } \\
\hline 3. Have the right to & $y$ please. & & $(77) 9.0$ & (68)8.5 \\
\hline 4. To chew or use & they like. & & (84)9.8 & $(67) 8.4$ \\
\hline 5. Do you plan to & cts when you ar & & (77)9.0 & $(46) 5.8$ \\
\hline \multicolumn{5}{|c|}{ Knowledge of Ellisras children on home made tobacco product } \\
\hline 1. Home made ciga & ne effect on you & ught ones do & $(243) 28.5$ & $(213) 26.6$ \\
\hline Home made cigare & e same effect o & e bought ones do & $(313) 36.7$ & $(328) 41.0$ \\
\hline There is no differen & made cigarette & & $(298) 34.9$ & $(259) 32.4$ \\
\hline \multicolumn{5}{|c|}{ Advertisement of Tobacco products on Television } \\
\hline How often do you & bacco product & ovie & (434) 50.8 & $(407) 50.9$ \\
\hline During the past 30 & o you see tobac & or logo on Television & (366) 42.9 & $(311) 38.9$ \\
\hline
\end{tabular}

whereas teachers and friends also contributed in influencing (20\%) older children (15-18 years).

\section{Discussions}

The aim of the study was to evaluate habits, beliefs and practices of Ellisras rural children regarding tobacco products usage. The overall results indicated an increase in the prevalence (about 17\%) of cigarette smoking by boys with age. Similar results were reported in South Africa nationally $[15,16]$ on children of similar age groups. The usage of cigarette smoking by girls in this Ellisras population did not exist. This was different from the $14.9 \%$ girls grade 8 to 11 and 5.2 to $7.5 \%$ girls aged 15 to 19 years reported in South Africa nationally $[15,16]$. However, the prevalence of smoking among the
Ellisras boys was lower compared to that of the Zambian boys (9.3\%) whereas smoking among the Zambian girls was high $(12.1 \%)$ as compared to findings of both the current study and the national survey in South Africa $[15,16,28]$.

The children further reported that they did not admire women who smoke cigarette. Smoking initiations in Ellisras rural boys starts between aged 11 to 12 and increases with increasing age. Similar results were reported in Hong Kong, Global Youth Tobacco Survey Project, Zambia and Cape Town for children between the age of 11 to 18 years or [28-31]. However, Damas et al. [32] and Wen et al. [33] reported that most smokers had parents $(\mathrm{n}=111,57 \%)$, as well as friends who smoked $(\mathrm{n}=187,96.4 \%)$. Children who are surrounded 
Table 3 Frequencies and percentage frequencies for attitude of tobacco products for the Ellisras rural area children aged 11 to 18 years

\begin{tabular}{|c|c|c|c|c|c|c|}
\hline & $\begin{array}{l}\text { They look cool } \\
\text { (n)\% }\end{array}$ & $\begin{array}{l}\text { Rich and successful } \\
\text { (n)\% }\end{array}$ & $\begin{array}{l}\text { Stupid } \\
\text { (n)\% }\end{array}$ & $\begin{array}{l}\text { Like losers } \\
\text { (n)\% }\end{array}$ & $\begin{array}{l}\text { Very happy } \\
\text { (n)\% }\end{array}$ & $\begin{array}{l}\text { No difference } \\
\text { (n)\% }\end{array}$ \\
\hline \multicolumn{7}{|c|}{ Attitude of Ellisras rural children on Tobacco products } \\
\hline \multicolumn{7}{|c|}{ Boys } \\
\hline 1. TV star smoking cigarette. & $(168) 19.7$ & $(56) 6.6$ & (245)28.7 & (189)22.1 & (133) 15.6 & $(63) 7.4$ \\
\hline 2. Men smoking cigarette or pipe. & $(164019.7$ & $(51) 6.0$ & (256)30.0 & (238)27.9 & (94)11.0 & $(51) 6.0$ \\
\hline 3. Men chewing tobacco and using snuff. & $(130) 15.2$ & (29)3.4 & $(378) 44.3$ & (196)23.0 & $(71) 8.3$ & $(50) 5.0$ \\
\hline 4. Women smoking pipe or cigarette. & (99)11.6 & $(41) 4.8$ & $(403) 47.2$ & (167)19.6 & $(86) 10.1$ & $(58) 6.8$ \\
\hline 5. Women chewing tobacco or snuff. & $(121) 14.2$ & (14) 4.8 & $(351) 41.1$ & (196) 23.0 & $(79) 9.3$ & $(66) 7.7$ \\
\hline \multicolumn{7}{|l|}{ Girls } \\
\hline 1. TV star smoking cigarette. & (153) 19.1 & $(47) 5.9$ & $(254) 31.8$ & $(182) 22.8$ & $(84) 10.5$ & (80) 10.0 \\
\hline 2. Men smoking cigarette or pipe. & (150) 18.8 & $(57) 7.1$ & (235)29.4 & $(218) 27.3$ & (90011.3 & $(50) 6.3$ \\
\hline 3. Men chewing tobacco and using snuff. & $(121) 15.1$ & $(25) 3.1$ & $(360045.0$ & (177)22.1 & 97609.5 & $(41) 5.1$ \\
\hline 4. Women smoking pipe or cigarette. & $(107) 13.4$ & $(35) 4.4$ & $(337) 42.1$ & $(202) 25.3$ & $(67) 8.4$ & $(52) 6.1$ \\
\hline 5. Women chewing tobacco or snuff. & (125)15.6 & $(40) 5.0$ & $(327) 40.9$ & (187)23.4 & $(66) 8.3$ & $(55) 6.7$ \\
\hline
\end{tabular}

by smoking friends and family members are more likely to be smokers $[34,35]$. Similar discoveries were found among the Ellisras rural children since the use of tobacco product by family members and visitors is a normal practice (more that $80 \%$ reported less than ten people using tobacco product at their home) (Table 2).
In addition, there was a significant $(\mathrm{p}<0.001)$ association $(\mathrm{OR}=2.3395 \% \mathrm{CI} 1.4 ; 4.0$ and $\mathrm{OR} 2.08,95 \% \mathrm{CI}$ 1.2; 3.6 after adjusting for age and gender) between tobacco products use and the possibility of using tobacco products as an adult by the Ellisras rural children.

Table 4 Odds ratio and $95 \%$ confidence interval for the association of tobacco products use, attitudes and habits of tobacco products use among Ellisras rural children aged 11 to 18 years

\begin{tabular}{|c|c|c|c|c|c|c|c|c|c|c|c|c|}
\hline & \multicolumn{6}{|l|}{ Unadjusted } & \multicolumn{6}{|c|}{ Adjusted for age and gender } \\
\hline & $\begin{array}{l}\text { They look } \\
\text { cool }\end{array}$ & $\begin{array}{l}\text { Rich and } \\
\text { successful }\end{array}$ & stupid & $\begin{array}{l}\text { Like } \\
\text { losers }\end{array}$ & $\begin{array}{l}\text { Very } \\
\text { happy }\end{array}$ & $\begin{array}{l}\text { No } \\
\text { difference }\end{array}$ & $\begin{array}{l}\text { They look } \\
\text { cool }\end{array}$ & $\begin{array}{l}\text { Rich and } \\
\text { successful }\end{array}$ & stupid & $\begin{array}{l}\text { Like } \\
\text { losers }\end{array}$ & $\begin{array}{l}\text { Very } \\
\text { happy }\end{array}$ & $\begin{array}{l}\text { No } \\
\text { difference }\end{array}$ \\
\hline & $\begin{array}{l}\text { OR }(95 \% \\
\text { CI) }\end{array}$ & $\begin{array}{l}\text { OR } \\
(95 \% \mathrm{Cl})\end{array}$ & $\begin{array}{l}\text { OR } \\
(95 \% \mathrm{Cl})\end{array}$ & $\begin{array}{l}\text { OR } \\
(95 \% \mathrm{Cl})\end{array}$ & $\begin{array}{l}\text { OR } \\
\text { (95\%Cl) }\end{array}$ & $\begin{array}{l}\text { OR } \\
(95 \% \mathrm{Cl})\end{array}$ & $\begin{array}{l}\text { OR }(95 \% \\
\text { Cl) }\end{array}$ & $\begin{array}{l}\text { OR } \\
(95 \% \mathrm{Cl})\end{array}$ & $\begin{array}{l}\text { OR } \\
(95 \% \\
\mathrm{Cl})\end{array}$ & $\begin{array}{l}\text { OR } \\
(95 \% \mathrm{Cl})\end{array}$ & $\begin{array}{l}\text { OR } \\
(95 \% \mathrm{Cl})\end{array}$ & $\begin{array}{l}\text { OR }(95 \% \\
\mathrm{Cl})\end{array}$ \\
\hline \multicolumn{13}{|c|}{ Attitude of Ellisras rural children on Tobacco products } \\
\hline TVSS & $\begin{array}{l}1.2 \\
(0.7 ; 1.8)\end{array}$ & $\begin{array}{l}2.3^{*} \\
(1.3 ; 4.1)\end{array}$ & $\begin{array}{l}0.8 \\
(0.5 ; 1.2)\end{array}$ & $\begin{array}{l}0.8 \\
(0.5 ; 1.3)\end{array}$ & $\begin{array}{l}1.2 \\
(0.7 ; 1.9)\end{array}$ & $\begin{array}{l}0.8 \\
(0.4 ; 1.6)\end{array}$ & $\begin{array}{l}1.2 \\
(0.7 ; 1.8)\end{array}$ & $\begin{array}{l}2.3^{*} \\
(1.3 ; 4.1)\end{array}$ & $\begin{array}{l}0.8 \\
(0.5 ; 1.2)\end{array}$ & $\begin{array}{l}0.8 \\
(0.5 ; 1.3)\end{array}$ & $\begin{array}{l}1.0 \\
(0.6 ; 1.7)\end{array}$ & $\begin{array}{l}0.8 \\
(0.4 ; 1.7)\end{array}$ \\
\hline MS & $\begin{array}{l}0.9 \\
(0.5 ; 1.4)\end{array}$ & $\begin{array}{l}1.5 \\
(0.8 ; 2.8)\end{array}$ & $\begin{array}{l}0.7 \\
(0.4 ; 1.0)\end{array}$ & $\begin{array}{l}1.2 \\
(0.8 ; 1.8)\end{array}$ & $\begin{array}{l}1.1 \\
(0.6 ; 1.8)\end{array}$ & $\begin{array}{l}1.6 \\
(0.9 ; 3.1)\end{array}$ & $\begin{array}{l}0.9 \\
(0.5 ; 1.4)\end{array}$ & $\begin{array}{l}1.6 \\
(0.8 ; 3.0)\end{array}$ & $\begin{array}{l}0.6^{*} \\
(0.4 ; 1.0)\end{array}$ & $\begin{array}{l}1.2 \\
(0.8 ; 1.7)\end{array}$ & $\begin{array}{l}1.1 \\
(0.6 ; 1.9)\end{array}$ & $\begin{array}{l}1.7 \\
(0.9 ; 3.3)\end{array}$ \\
\hline MCT & $\begin{array}{l}1.4 \\
(0.9 ; 2.2)\end{array}$ & $\begin{array}{l}1.2 \\
(0.5 ; 3.1)\end{array}$ & $\begin{array}{l}0.8 \\
(0.6 ; 1.2)\end{array}$ & $\begin{array}{l}1.0 \\
(0.6 ; 1.5)\end{array}$ & $\begin{array}{l}0.6 \\
(0.3 ; 1.2)\end{array}$ & $\begin{array}{l}1.9^{*} \\
(1.0 ; 3.5)\end{array}$ & $\begin{array}{l}1.4 \\
(0.9 ; 2.2)\end{array}$ & $\begin{array}{l}1.2 \\
(0.5 ; 3.2)\end{array}$ & $\begin{array}{l}0.8 \\
(0.6 ; 1.2)\end{array}$ & $\begin{array}{l}1.0 \\
(0.6 ; 1.5)\end{array}$ & $\begin{array}{l}0.6 \\
(0.3 ; 1.3)\end{array}$ & $\begin{array}{l}1.8 \\
(0.9 ; 3.4)\end{array}$ \\
\hline WS & $\begin{array}{l}1.1 \\
(0.7 ; 1.9)\end{array}$ & $\begin{array}{l}2.8^{*} \\
(1.5 ; 5.2)\end{array}$ & $\begin{array}{l}0.7 \\
(0.5 ; 1.0)\end{array}$ & $\begin{array}{l}0.9 \\
(0.6 ; 1.4)\end{array}$ & $\begin{array}{l}1.2 \\
(0.7 ; 2.2)\end{array}$ & $\begin{array}{l}1.0 \\
(0.5 ; 2.1)\end{array}$ & $\begin{array}{l}1.2 \\
(0.7 ; 2.1)\end{array}$ & $\begin{array}{l}2.9^{* *} \\
(1.5 ; 5.4)\end{array}$ & $\begin{array}{l}0.6^{*} \\
(0.4 ; 0.9)\end{array}$ & $\begin{array}{l}1.0 \\
(0.6 ; 1.6)\end{array}$ & $\begin{array}{l}1.2 \\
(0.6 ; 2.1)\end{array}$ & $\begin{array}{l}1.0 \\
(0.5 ; 2.1)\end{array}$ \\
\hline WCT & $\begin{array}{l}0.6 \\
(0.3 ; 1.1)\end{array}$ & $\begin{array}{l}1.5 \\
(0.7 ; 3.1)\end{array}$ & $\begin{array}{l}1.1 \\
(0.7 ; 1.5)\end{array}$ & $\begin{array}{l}0.7 \\
(0.4 ; 1.1)\end{array}$ & $\begin{array}{l}1.7^{*} \\
(1.0 ; 2.8)\end{array}$ & $\begin{array}{l}1.5 \\
(0.8 ; 2.7)\end{array}$ & $\begin{array}{l}0.7 \\
(0.4 ; 1.2)\end{array}$ & $\begin{array}{l}1.6 \\
(0.8 ; 3.3)\end{array}$ & $\begin{array}{l}1.1 \\
(0.7 ; 1.5)\end{array}$ & $\begin{array}{l}0.7( \\
0.4 ; 1.1)\end{array}$ & $\begin{array}{l}1.6 \\
(0.9 ; 2.7)\end{array}$ & $\begin{array}{l}1.4 \\
(0.8 ; 2.6)\end{array}$ \\
\hline \multicolumn{13}{|c|}{ Habits of Ellisras children of tobacco products } \\
\hline & & & & & & \multirow{2}{*}{\multicolumn{3}{|c|}{$\begin{array}{l}\text { Unadjusted } \\
\mathrm{OR}(\mathrm{Cl})\end{array}$}} & \multirow{2}{*}{\multicolumn{4}{|c|}{$\begin{array}{l}\text { Adjusted for age and gender } \\
\text { OR }(\mathrm{Cl})\end{array}$}} \\
\hline & & & & & & & & & & & & \\
\hline \multicolumn{6}{|c|}{ For people to smoke in public places. } & \multicolumn{3}{|l|}{$1.17(0.7 ; 1.9)$} & \multicolumn{4}{|c|}{$1.15(0.7 ; 1.9)$} \\
\hline \multicolumn{6}{|c|}{ For people to chew tobacco in public places. } & \multicolumn{3}{|l|}{$0.82(0.5 ; 1.3)$} & \multicolumn{4}{|c|}{$0.82(0.5 ; 1.3)$} \\
\hline \multicolumn{6}{|c|}{$\begin{array}{l}\text { Do you believe that people have the right to smoke where they } \\
\text { please }\end{array}$} & \multicolumn{3}{|l|}{$2.32^{* *}(1.4 ; 3.8)$} & \multicolumn{4}{|c|}{$2.31^{* *}(1.4 ; 3.9)$} \\
\hline \multicolumn{6}{|c|}{$\begin{array}{l}\text { Do you believe that people have to chew or use tobacco } \\
\text { anywhere they like. }\end{array}$} & \multicolumn{3}{|l|}{$1.44(0.8 ; 2.5)$} & \multicolumn{4}{|c|}{$1.4(0.8 ; 2.4)$} \\
\hline \multicolumn{6}{|c|}{ Do you plan to use tobacco products when you are an adult? } & \multicolumn{3}{|l|}{$2.33^{* *}(1.4 ; 4.0)$} & \multicolumn{4}{|c|}{$2.08^{* *}(1.2 ; 3.6)$} \\
\hline
\end{tabular}




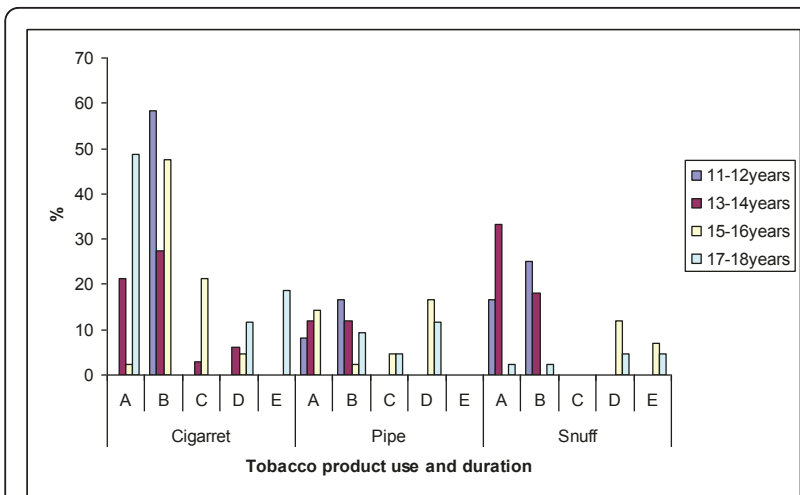

Figure 1 The estimated period during which the Ellisras rural boys first start to use tobacco product.

Tobacco advertising bans have been effective in reducing consumption in a number of countries including South Africa, Zambia, New Zealand, Canada where the ban has been associated with the rapid decline in tobacco consumptions [28,36,37]. Yang et al. [38] reported that children admire their doctors when they smoke. However, the overall impact of tobacco advertisement by TV stars and some role models who use tobacco products openly in the community was two-fold in this Ellisras rural community. Firstly, it starts as a stimulant to viewers to start smoking, thus supporting the impression that it is a socially desirable activity. For example, the children in the current study significantly $(\mathrm{p}<0.05)$ view TV stars who smoke as rich and successful (OR 2.3 95\% CI 1.3;4.1 and OR $2.395 \%$ CI 1.3;4.1) after adjusting for age and gender). Zulu et al. [28] also reported a positive association between seeing a TV star smoking and the smoking behaviour among Zambian adolescents (OR = 1.90; 95\% CI 1.26, 2.88). Secondly, though tobacco products cost

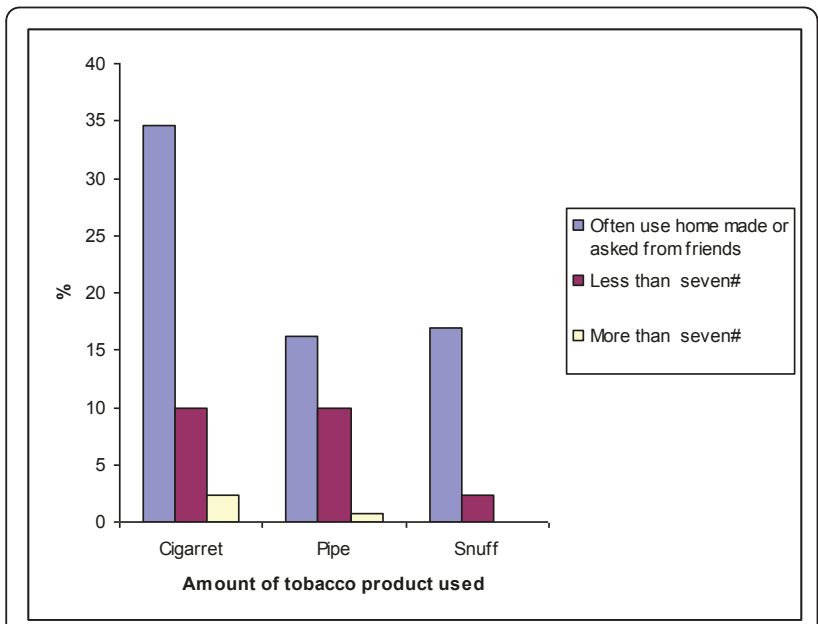

Figure 2 The amount of tobacco product use by Ellisras rural boys age 11 to 18 year.

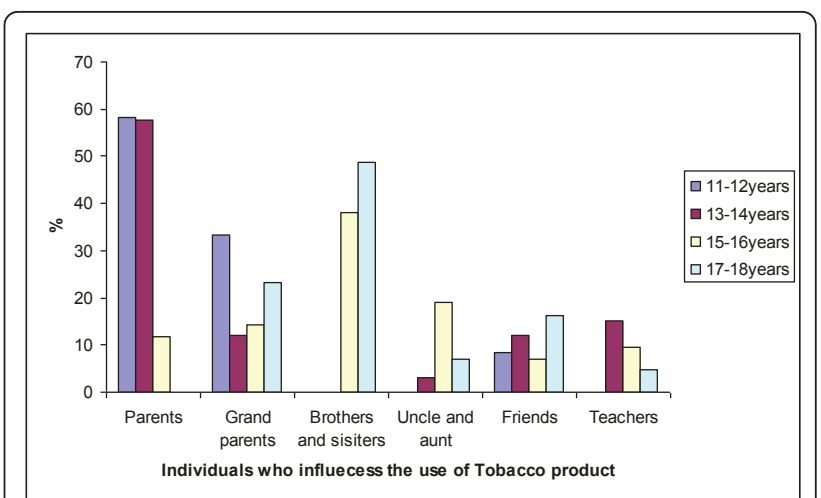

Figure 3 Who influence the Ellisras rural boys to start using the tobacco products.

increases yearly in South Africa, it seems to have resulted in the underestimation of its impact on tobacco use relative to a range of other public health issues. For example, in the current study, over $70 \%$ of the Ellisras children view home made cigarette as not having the same effect on one's health as the bought ones. Ultimately adolescents opted for the home made ones so as to imitate the TV stars, men and women who use tobacco in the Ellisras community.

Habits and beliefs in this Ellisras rural community appear to be central to the escalating use of tobacco products. In this study grand parents and parents were the most influential (50\%) people to the children who smoke especially that the majority of the participants used home made or indigenous tobacco products (Figure 2). The possible explanation of this behaviour might be that boys in these communities spent most of their time outside their homes (engaged in animal husbandry and cattle rearing) and thus were exposed to people who use indigenous tobacco products as compared to their female counterparts (i.e. girls), who spent most of their time at home engaged in house chores, such as cooking, cleaning, fetching water and washing their family clothes, etc. On the one hand it is still a cultural taboo for a woman to smoke, let alone girls in Ellisras rural area. Similar trends are observable in Global Youth Tobacco Survey (GYTS) in countries that are still conservative like India and other parts of developing countries [39].

The South African Tobacco Product Control Act of 1993 and its amendments in 1999 and 2007 provides a hopeful paradigm shift in the use of tobacco products in the quest for the improvement of health and provision of awareness in communities about mortality emanating from chronic diseases. The findings of this study suggest that to succeed in these efforts, eradication of illiteracy should be the first hurdle to jump by health professionals in terms of providing primary health to these sectors of the community $[40,41]$. The South African population 
should make strides to shift from the traditional knowledge and medication, and seek new innovative ways of addressing issues facing the population with regard to health, climate, environment and lifestyle changes in line with the ongoing political transformation.

We acknowledge that we did not consider the socio-economic status of families of the participants in the analysis. Furthermore, our study is cross-sectional in nature. Many changes are taking place in South Africa today, which are of concern. These include the adoption of western diets, hence the changing of lifestyles which include among others, excessive use of contemporary tobacco products and an increase level of alcohol usage [42,43]. Also, a follow up on the use of tobacco products may shed more light on how smoking is related to other biological parameters in this population. Furthermore, the role of schools in the teaching of health education, to curb the escalating drug abuse in the South African schools will be helpful.

\section{Conclusions}

The prevalence of tobacco use increase with increasing age among boys. Girls do not smoke but use snuff. Ellisras rural children do not admire women who smoke. The findings of this study have at least two implications for both public health and education authorities respectively. Firstly, for the public health sector, there is an urgent need to carry out intervention programmes that can boost primary health facilities to provide information regarding adverse effects in this community, something that includes the home made tobacco products usage. Secondly, for the education sector, there is also an urgent need to include health education in the curriculum to address the risk behaviour among children who smoke. For example, policy makers in education should begin to introduce life skills programmes that address this health hazard.

\section{Acknowledgements}

The financial support received from Vrije University, Amsterdam, The Netherlands and the University of Limpopo, South Africa, National Research Foundation and the Medical Research Council of South Africa for the Ellisras Longitudinal Growth and Health study is also acknowledged with gratitude. Any opinion, findings and conclusions or recommendations expressed in this material are those of the authors and therefore the above mentioned funding sources do not accept any liability in regard thereto. The authors are in dept to Ellisras Longitudinal Study administrators (Majadibodu J, Seleka P and Tselapedi PP) for providing technical support in preparation of this manuscript. Monyeki MS and Malatji MJ (Makgoka Secondary School, Limpopo Province) are thankfully acknowledged for editing this manuscript.

\section{Author details}

'Department of Educational Studies, University of Limpopo, Sovenga, South Africa. ${ }^{2}$ Chronic Disease of lifestyle unit, Medical Research Council, Tygerberg, 7505, South Africa. ${ }^{3}$ VU University Medical Centre, The Institute for Health and Care Research (EMGO+), Amsterdam, the Netherlands.

\section{Authors' contributions}

RJM participated in the design, coordinated the data collection and critical revision of the manuscript for important intellectual content. MJT participated in the study design and critical revision of the manuscript for important intellectual content. KDM participated in the study design, data collection, analysis and interpretation of data, drafting of the manuscript, critical revision of the manuscript for important intellectual content and administrative, technical, and material support, such as supervision of the study. HCGK participated in study the design, data analysis, interpretation and critical revision of the manuscript for important intellectual content. All of the authors read and approved the final version of the manuscript.

\section{Competing interests}

The authors declare that they have no competing interests.

Received: 15 January 2011 Accepted: 23 June 2011

Published: 23 June 2011

\section{References}

1. Wald NJ, Watt HC: Prospective study of effect of switching from cigarettes to pipes or cigars on mortality from three smoking related diseases. Br Med J 1997, 314:1860-1863.

2. Doll R: Uncovering the effects of smoking. Historical perspective. Stat Methods Med Res 1998, 87-117.

3. Schildt E, Erikson M, Hardell L, Magnuson A: Oral Snuff, smoking habits and alcohol consumption in relation to oral cancer in a Swedish casecontrol study. Int J Cancer 1998, 7:341-346.

4. Armadans-Gil L, Vaque-Rafart J, Rosselló J, Olona M, Alseda M: Cigarette smoking and the lung cancer risk with special regard to type of tobacco. Int J Epidemiol 1999, 2:614-619.

5. Lakier JB: Smoking and cardiovascular disease. AM J Med 1992, 9:7-11.

6. Prescott $E$, Hippe M, Schnohr $\mathrm{P}$, Hein $\mathrm{HO}$, Vestbo J: Smoking and risk of myocardial infarction in women and men: Longitudinal population study. Br Med J 1998, 316:1043-1044.

7. Martin G, Steyn K, Yach D: Belief about smoking and health and attitudes toward tobacco control measures. S Afr Med J 1992, 82:241-245.

8. King G, Flisher AJ, Mallet R, Reece R, Marais A, Lombard C: Smoking Influences in Cape Town: Community Influences on Adolescent Tobacco Use. Prev Med 2002, 36:114-123.

9. Monyeki KD, Kemper HCG, Twisk JWR: Trends in obesity and hypertension in South African youth. In Childhood obesity prevention International Research, controversies and interventions. Edited by: O' Dea JA, Eriksen M. New York: Oxford University Press; 2010:44-151.

10. Peto R: Smoking and death: the past 40 years and the next 40 . BMJ 1994, 309:937-939.

11. Lopez AD, Collishaw NE, Piha T: A descriptive model of the cigarette epidemic in developed countries. Tob Control 1994, 3:242-247.

12. Al-Damegh SA, Saleh MA, Al-Hogail IM: Cigarette smoking behaviour among male secondary school students in the Central region of Saudi Arabia. Saudi Med J 2004, 25:215-219.

13. Steyn K, Bradshow D, Norman R, Bradley H, Laubscher R: Research team of the South African Demographic and Health Survey: Tobacco use in South Africans during 1998: the first Demographic and health. J Cardiovasc Risk 2002, 9:161-170.

14. Reddy P, Meyer-Weitz A: Smoking status, knowledge of health effects and attitudes towards tobacco control in South in South Africa. $S$ Afr Med J 1996, 86:1389-1393.

15. Reddy SP, Panday S, Swart D, Jinabali CC, Amosun SL, James S, Monyeki KD, Stevens G, Morejele N, Kambaran NS, Omardien RG, Van den Borne HW: Umthenthe Uhlaba Usamila- The South African Youth Risk Behavior survey 2002. Cape Town: South African Medical Research Council; 2003, $17-36$.

16. Department of Health, Medical Research Council, OrcMacro: South Africa Demographic and Health Survey 2003. Pretoria: Department of Health; 2007, 164-165

17. Sidiropoulos E, Jeffery A, Mackay S, Gallocher R, Forgey H, Chips C: South Africa Survey 1995/1996. Johannesburg: South African Institute of Race and Relations; 1996, 234-360.

18. Bradshaw D, Steyn K: Poverty and chronic disease in South Africa: Technical Report. Cape Town: Medical Research Council; 2001, 38-45.

19. Statistics South Africa: Cause of death in South Africa 1997-2001: Advance release of records of death. Pretoria:Statistics South Africa; 2002, 18-42.

20. Themane MJ, Monyeki KD, Nthangeni ME, Kemper HCG, Twisk JWR: The relationship between health (malnutrition) and educational achievement 
(Maths and English) in the rural children of South Africa. Int J Ed Dev 2003, 23:637-643.

21. Fleisch B: Primary Education in Crisis. Why South African schoolchildren underachieve in reading and mathematics. Cape Town: Juta Publishers; 2008, 23-33.

22. Matabane MB, Monyeki KD, Themane MJ, Toriola AL, Monyeki MA, Brits SJ, Amusa LO, Kangolle ACT: Physical growth and educational achievement of the rural South African children: Ellisras Longitudinal Study. AJPHERD 2004, 10(4):317-325.

23. Themane MJ, Koppes LLJ, Kemper HCG, Monyeki KD, Twisk JWR: The relationship between socio-economic status and educational achievements of Ellisras rural primary school children. AJPHERD 2006, 12(3):298-309.

24. Monyeki KD, Van Lenthe FJ, Steyn NP: Obesity: Does it occur in African children in a rural community. Int J Epidemiol 1999, 28:287-292.

25. Monyeki KD, Cameron N, Getz B: Growth and nutritional status of rural South African children 3-10 years old: The Ellisras Growth Study. Am J Hum Biol 2000, 12:42-49.

26. Steyn K, de Wet T, Saloojee Y, Nel H, Yach D: The influence of maternal cigarette smoking, snuff use and passive smoking on pregnancy outcome: the Birth To Ten Study. Paediatric Perinat Epidemio 2006, 20(2):90-99.

27. Bernaards CM, Twisk JW, Snel J, van Mechelen W, Kemper HC: yln a prospective study in young people, associations between changes in smoking behaviour and risk factors for cardiovascular disease were complex. J Clin Epidemiol 2005, 58(11):1165-71.

28. Zulu R, Siziya S, Muula AS, Rudatsikira E: Association of advertisingpromotion-sponsorship-related factors with current cigarette smoking among in-school adolescents in Zambia. Ann Afr Med 2009, 8:229-235.

29. Lam TH, Chung SF, Betson CL Wong CM, Hedley AJ: Tobacco advertisement of the strongest Risk Factors for Smoking in Hong Kong Students. Am J Prev Med 1998, 14:217-223.

30. Warren CW, Riley L, Asma S, Eriksen MP, Green L, Blanton C, Loo C, Batchelor S, Yach D: Tobacco use by youth: a surveillance report from the Global Youth Tobacco Project. Bull World Health Organ 2000, 78(7):868-867.

31. King G, Flisher AJ, Mallett R, Graham J, Lombard C, Rawson T, Morojele NK, Muller M: Smoking in Cape Town: Community influence on adolescent Tobacco use. Prev Med 2003, 36:114-123.

32. Damas AC, Saleiro $S$, Marinho A, Fernandes G, Gomes I: Smoking habits in secondary school students. Revista Portugues de Pneumol 2009, 15:43-53.

33. Wen X, Chen W, Muscat JE, Muscat JE, Lu C, Ling W: Modifiable family and school environmental factors associated with smoking status among adolescents in Guangzhou, China. Prev Med 2007, 45:189-197.

34. Llyod-Richardson EE, Papandonas G, Kazura A, Stanton C, Niaura R: Differentiating stages of smoking intensity among adolescents stagespecific psychological and social influences. J Consult Clin Psychol 2002, 7:998-1009.

35. Leatherdale ST, McDonald P, Cameroon R, Brown KS: Multilevel analysis examining the relationship between social influences for smoking and smoking onset. Am J Health Behav 2005, 29:520-530.

36. Yach D, Peterson G: Tobacco advertising in South Africa with specific reference to Magazines. SAMJ 1994, 84:838-841.

37. Amos A: Cigarette advertising and marketing strategies. Tob Control 1992, 1:3-4.

38. Yang G, Ma J, Chen AP, Brown S, Taylor CE, Samet JM: Smoking among adolescents in China: 1998 survey findings. Int J Epidemiol 2004, 33:1103-1110

39. Delpisheh A, Kelly Y, Brabin BJ: Passive cigarette smoke exposure in primary school children in Liverpool. Public Health 2006, 120:65-69.

40. Kemper HCG: Amsterdam growth and Health longitudinal study: A 23 year follow up from teenager to adult about lifestyle and health. New York: Karger; 2004, 1-20.

41. Monyeki KD, Kemper HCG: The risk factors for elevated blood pressure and how to address cardiovascular risk factors: A review in paediatric population. J Hum Hypertens 2008, 22:450-459.

42. Labadarios D, Steyn NP, Maunder E, Maclntryre U, Gericke G, Swart R: The National Food Consumption survey: Children aged $1-9$ years, South Africa, 1999. Pretoria: Department of Health; 2000Chapter 2.
43. Steyn K, De Wet T, Richter L, Cameron N, Levitt NS, Morrell C: Cardiovascular diseases risk factors in 5-year -old urban South African children: The Birth to Ten Study. SAM J 2000, 90(7):719-725.

\section{Pre-publication history}

The pre-publication history for this paper can be accessed here: http://www.biomedcentral.com/1471-2431/11/58/prepub

doi:10.1186/1471-2431-11-58

Cite this article as: Mashita et al:: Current smoking behaviour among rural South African children: Ellisras Longitudinal Study. BMC Pediatrics 2011 11:58.

\section{Submit your next manuscript to BioMed Central and take full advantage of:}

- Convenient online submission

- Thorough peer review

- No space constraints or color figure charges

- Immediate publication on acceptance

- Inclusion in PubMed, CAS, Scopus and Google Scholar

- Research which is freely available for redistribution

Submit your manuscript at www.biomedcentral.com/submit 